Short Paper

\title{
Potential of cow dung as insect herbivore repellent on Cowpea (Vigna unguiculata)
}

\author{
A.L. Ogunyebi ${ }^{1 *}$, A. Olubiyo ${ }^{1}$, K. O. Omoyajowo ${ }^{1,2}$, T.S. Fingesi ${ }^{1}$ \\ ${ }^{1}$ Department of Cell Biology and Genetics, University of Lagos, Akoka, Lagos, Nigeria \\ ${ }^{2}$ Department of Science Policy and Innovation Studies, National Centre for Technology \\ Management, Victoria Island, Lagos, Nigeria \\ *Correspondence: logunyebi@unilag.edu.ng; (iD https://orcid.org/0000-0003-2315-470X
}

Received: $27^{\text {th }}$ May 2018, Revised: $13^{\text {th }}$ November 2018, Accepted: $13^{\text {th }}$ May 2019

\begin{abstract}
This study examined the potential of using cow dung as a repellent of herbivore pest on cowpea (Vigna unguiculata) and the work was carried out in the botanical and zoological garden of the University of Lagos, Akoka, Lagos, Nigeria. Four accessions of cowpea were grown in the soil samples collected from the Botanical and Zoological garden of the University of Lagos. The experiment was arranged in a randomized block design with three replicates to monitor the potential of using cow dung as a repellent of herbivore pest on cowpea for a period of six weeks. The data collected was analyzed using ANOVA. The results showed that cow dung treatments did not have significant effect $(\mathrm{P}>0.05)$ in repelling the insects of cowpeas. However, the plants treated with high concentrations of cow dung attracted significantly $(\mathrm{P}<0.05)$ higher number of insect pests and as the days of the application of the treatments increases, the number of leaves damaged by the insects increases. The study therefore recommends that a further study should be carried out using some other different plants species at different locations and different environmental conditions.
\end{abstract}

Keywords: Cow dung, cowpea, insect repellent

\section{Introduction}

Cowpea Vigna unguiculata is an economically important food crop which is a source of plant protein, minerals, lipids and vitamins for humans and livestock (Dolvo et al. 2014). It is valued as a cheap source of protein for many people that could not afford for animal protein such as meat, fish, and eggs in Nigeria. It is processed in various form but often consumed as "moi-moi" and "akara"- a special delicacy often traded by roadside food vendors in Nigeria 
for public consumption. It is mainly grown in Northern Nigeria but its cultivation has recently extended to Southern part of Nigeria where it is cultivated in the Western and Eastern part respectively (Emosairue et al. 2014).

Cowpea has different pests that pose great threat to its proper growth and yield (Nampala et al. 1999, Ajeigbe and Singh 2006). Major insect pests that cause severe damage to cowpea during growth stages include; cowpea aphid (Aphis craccivora Koch), foliage beetles (Ootheca spp.)and Medythia spp.), the flower bud thrips (Megalurothripssj ostedti Tryb) the legume pod borer (Marucavitrata fabricius) and the sucking bug complex of which species such as Clavigralla spp., Anoplocnemis spp., Riptortus spp., Mirperus spp., Nezara viridula and Aspavia armigera are the .most important and prevalent (Olatunde et al. 2013). Pod bugs for example suck sap from green pods, causing abnormal pod and seed formation and yield losses of 30-70\% (Sexena 2010).

The prevalence and distribution of cowpea insect pests may however be influenced by some factors. Recent study suggested that the use of effluent water to irrigate crops may increase incidence, abundance and damage caused by cowpea insect pests possibly reducing cowpea plant productivity and vigor (Tiroesele et al. 2017). Sawadogo et al. (2009) also posited that there may be variation in prevalence and distribution of cowpea insect pest among agroclimatic zones. Two common aphid parasites, Lysiphlebus spp. and Diaeretiella spp. have also been identified as major parasites that determine the abundance of aphids (UCANR 2017). Hence, their presence on fields may reduce the abundance of aphids. The use of biological control of insect pest of cowpea is receiving attention lately. This is because conventional methods such as synthetic insecticides cannot be used to control these pests for safe and sustainable cowpea production.

Taken together, cowpea is an important crop but insect pest is a cultivation-constrain. Moreover, insecticide applications are costly and have many environmental consequences including direct human health hazards. Hence, it requires alternate non-chemical approach toward insect pest control. Cow dung could be a good option since a number of studies have documented its insect-repellent nature (Okogbue and Ojo 2003, Mandavgane et al. 2005). Hence, in this study insect-repellent nature of cow dung is tested on cowpea.

\section{Material and Methods}

\subsection{Study Area}

The experiment was carried out in the botanical and zoological garden of University of Lagos, Akoka, Lagos which is situated in the North- East of 
Lagos, in the Yaba Local Government Area of Lagos State Nigeria. It lies in the latitude $6^{\circ} 31^{\prime} 0$ ' $\mathrm{N}$ and $3^{\circ} 23^{\prime} 10^{\prime} \mathrm{E}$ and longitude $6.51667^{\circ} \mathrm{N}$ and $3.38611^{\circ}$ E. The University is located within the tropical lowland region with two distinct seasons; the wet season is between March-October, while the dry season is between November-February. The mean annual rainfall is between $1250-2500 \mathrm{~mm}$, while the mean monthly temperature ranges between $25.7^{\circ} \mathrm{C}$ usually in July and $30.2^{\circ} \mathrm{C}$ in February.

\subsection{Experimental procedures}

Germination experiment was carried out for six weeks on the four accessions of cowpea collected from National Centre for Genetic Resources and Biotechnology (NACGRAB).Three seeds of each of the accessions were sown in plastic containers filled with soil collected from the Botanical and Zoological garden of the University of Lagos, Akoka, Lagos. The experiment was 4 x 4 factorial experiment laid out in Completely Randomized Design (CRD). The treatment combinations applied were three different concentrations of cow dung $(0 \%, 25 \%, 50 \%$ and $75 \% \mathrm{~V} / \mathrm{W})$ replicated three times. The treatments were applied six times after germination of the cowpea at 5 days interval $(5,10,15,20,25$, and 30 days respectively).

The treatment combinations are as follows:

$$
\begin{aligned}
& \mathrm{N}_{0} \mathrm{~L}_{0}=\mathrm{T}_{1}-\mathrm{NASA} / \mathrm{SA} / 07 / 028+0 \% \mathrm{CD} \\
& \mathrm{N}_{0} \mathrm{~L}_{1}=\mathrm{T}_{2}-\mathrm{NA} / \mathrm{SA} / 07 / 063+0 \% \mathrm{CD} \\
& \mathrm{N}_{0} \mathrm{~L}_{2}=\mathrm{T}_{3}-\mathrm{NA} / 10 / 11 / 08 / 047+0 \% \mathrm{CD} \\
& \mathrm{N}_{0} \mathrm{~L}_{3}=\mathrm{T}_{4}-\mathrm{NA} / \mathrm{SA} / 07 / 009+0 \% \mathrm{CD} \\
& \mathrm{N}_{1} \mathrm{~L}_{\mathrm{o}}=\mathrm{T} 5-\mathrm{NASA} / \mathrm{SA} / 07 / 028+25 \% \mathrm{CD} \\
& \mathrm{N}_{1} \mathrm{~L}_{1}=\mathrm{T} 6-\mathrm{NA} / \mathrm{SA} / 07 / 063+25 \% \mathrm{CD} \\
& \mathrm{N}_{1} \mathrm{~L}_{2}=\mathrm{T} 7-\mathrm{NA} / 10 / 11 / 08 / 047+25 \% \mathrm{CD} \\
& \mathrm{N}_{1} \mathrm{~L}_{3}=\mathrm{T} 8-\mathrm{NA} / \mathrm{SA} / 07 / 009+25 \% \mathrm{CD} \\
& \mathrm{N}_{2} \mathrm{~L}_{\mathrm{o}}=\mathrm{T} 9-\mathrm{NASA} / \mathrm{SA} / 07 / 028+50 \% \mathrm{CD} \\
& \mathrm{N}_{2} \mathrm{~L}_{1}=\mathrm{T} 10-\mathrm{NA} / \mathrm{SA} / 07 / 063+50 \% \mathrm{CD} \\
& \mathrm{N}_{2} \mathrm{~L}_{2}=\mathrm{T} 11-\mathrm{NA} / 10 / 11 / 08 / 047+50 \% \mathrm{CD} \\
& \mathrm{N}_{2} \mathrm{~L}_{3}=\mathrm{T} 12-\mathrm{NA} / \mathrm{SA} / 07 / 009+50 \% \mathrm{CD} \\
& \mathrm{N}_{3} \mathrm{~L}_{\mathrm{o}}=\mathrm{T} 13-\mathrm{NASA} / \mathrm{SA} / 07 / 028+75 \% \mathrm{CD} \\
& \mathrm{N}_{3} \mathrm{~L}_{1}=\mathrm{T} 14-\mathrm{NA} / \mathrm{SA} / 07 / 063+75 \% \mathrm{CD} \\
& \mathrm{N}_{3} \mathrm{~L}_{2}=\mathrm{T} 15-\mathrm{NA} / 10 / 11 / 08 / 047+75 \% \mathrm{CD} \\
& \mathrm{N}_{3} \mathrm{~L}_{3}=\mathrm{T} 16-\mathrm{NA} / \mathrm{SA} / 07 / 009+75 \% \mathrm{CD}
\end{aligned}
$$




\subsection{Data Analysis}

Data on cow dung treatment performance were subjected to analysis of variance (ANOVA) and the treatment mean were separated using Least Significant Difference (LSD). Pearson Correlation was used to show the relationship between the number of leaves damaged and number of days of the treatment. The statistical tool used was Graphpad prism 7.04.

\section{Results}

Table 1 showed the mean values of leaves damaged after the treatment. The result showed that $50 \%$ and $75 \%$ had the highest mean value of leaves damaged (T15 in accession NA/10/11/08/047), while the least number of leaves damaged was observed in control (T1, T4 and T12 in accessions NA/SA/07/028 and NA/SA/07/009).

Table 1: Mean values of the damaged leaves in each accession after treatment.

\begin{tabular}{lllll}
\hline Treatment & \multicolumn{1}{c}{ Control } & $25 \%$ & $50 \%$ & $75 \%$ \\
\hline T1 & 0 & 0.33 & 0.67 & 0.67 \\
T2 & 0.33 & 0.33 & 0.67 & 0.33 \\
T3 & 0.67 & 0.33 & 0.67 & 0.67 \\
T4 & 0 & 1 & 0.67 & 0.67 \\
T5 & 0.67 & 0.33 & 1.67 & 1 \\
T6 & 1.67 & 1.33 & 2 & 1.67 \\
T7 & 2 & 2 & 2 & 1.67 \\
T8 & 0.33 & 1.67 & 1.67 & 2 \\
T9 & 2.33 & 1 & 2.33 & 3.33 \\
T10 & 2.33 & 3.33 & 5 & 3.33 \\
T11 & 4.33 & 4 & 3.67 & 3.67 \\
T12 & 0 & 2.67 & 2 & 1.67 \\
T13 & 3 & 3.67 & 4 & 4.33 \\
T14 & 2.67 & 4.33 & 5.33 & 4 \\
T15 & 4.67 & 3.33 & 4.33 & 4.67 \\
T16 & 0.33 & 0.67 & 3 & 3 \\
\hline
\end{tabular}


Table 2. Analysis of variance for the mean values of damaged leaves in Vigna unquiculata

\begin{tabular}{lccclc}
\hline $\begin{array}{l}\text { Analysis of } \\
\text { Variance }\end{array}$ & SS & DF & MS & F (DFn, DFd) & P value \\
\hline $\begin{array}{l}\text { Treatment } \\
\text { (between columns) }\end{array}$ & 7.761 & 3 & 2.587 & $\begin{array}{l}\text { F (2.396, 35.94) } \\
=6.168\end{array}$ & $0.0032^{*}$ \\
$\begin{array}{l}\text { Individual } \\
\text { (between rows) }\end{array}$ & 117.1 & 15 & 7.804 & $\begin{array}{l}\text { F (15, 45) } \\
=18.61\end{array}$ & $<0.0001^{*}$ \\
$\begin{array}{l}\text { Residual (random) } \\
\text { Total }\end{array}$ & 18.87 & 45 & 0.4194 & & \\
\hline
\end{tabular}

* Significant at $\mathrm{p}<0.01$ probability level.

The results presented in Table 2 showed that there were significant differences among the treatment at $5 \%$ probability level for the three conditions $[\mathrm{F}(15,45)=18.61, \mathrm{p}=0.0001]$. Treatments 1-9, 11, 13 and 15 were not significant at $(\mathrm{P}>0.05)$.

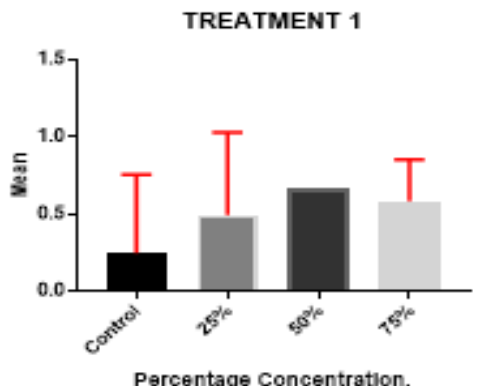

TREATMENT 3

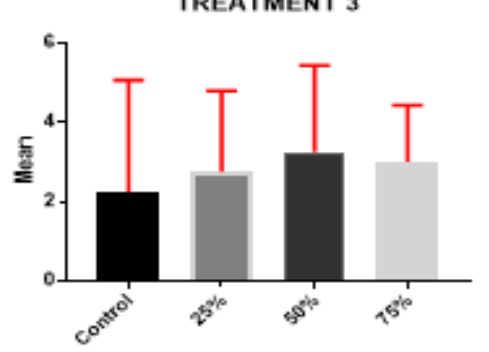

Percentage Concentration.

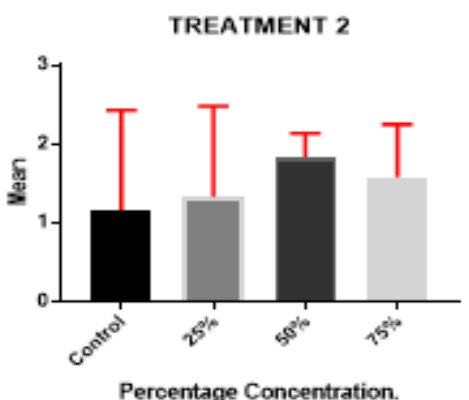

Percentage Concentration.

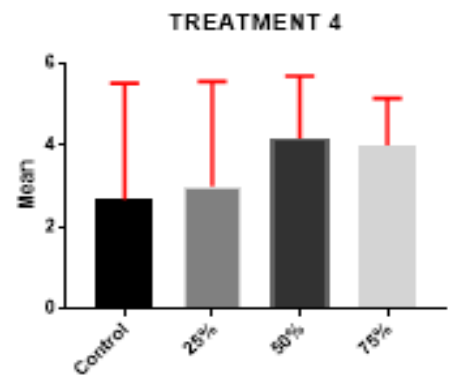

Percentage Concentration

Fig 1. Representation of leaves damaged for all the treatments on Vigna unquiculata 
However, Treatment 12 at $25 \%$ concentration was significant at $(\mathrm{P}<0.05)$ when compared to control. Similarly, Treatments 10,14, and 16 at 50\% concentration were significant at $(\mathrm{P}<0.05)$ while Treatments 16 at $75 \%$ concentration was strongly significant at $(\mathrm{P}<0.05)$ as shown in Figure 1.

\subsection{Treatment Performance}

Leaves damaged in all the accessions of Vigna unquiculata with increased in the number of days are shown in Figure 2. Leaves damaged increases with increasing number of days of exposure to cow dung in all the accessions of Vigna unquiculata. Major insect pest identified in all accessions were cowpea aphid (Aphis caraccivora Koch), legume bud thrips (Megalurothrips sjostedti Tryb) and armyworm (Spodoptera exigua Hübner).

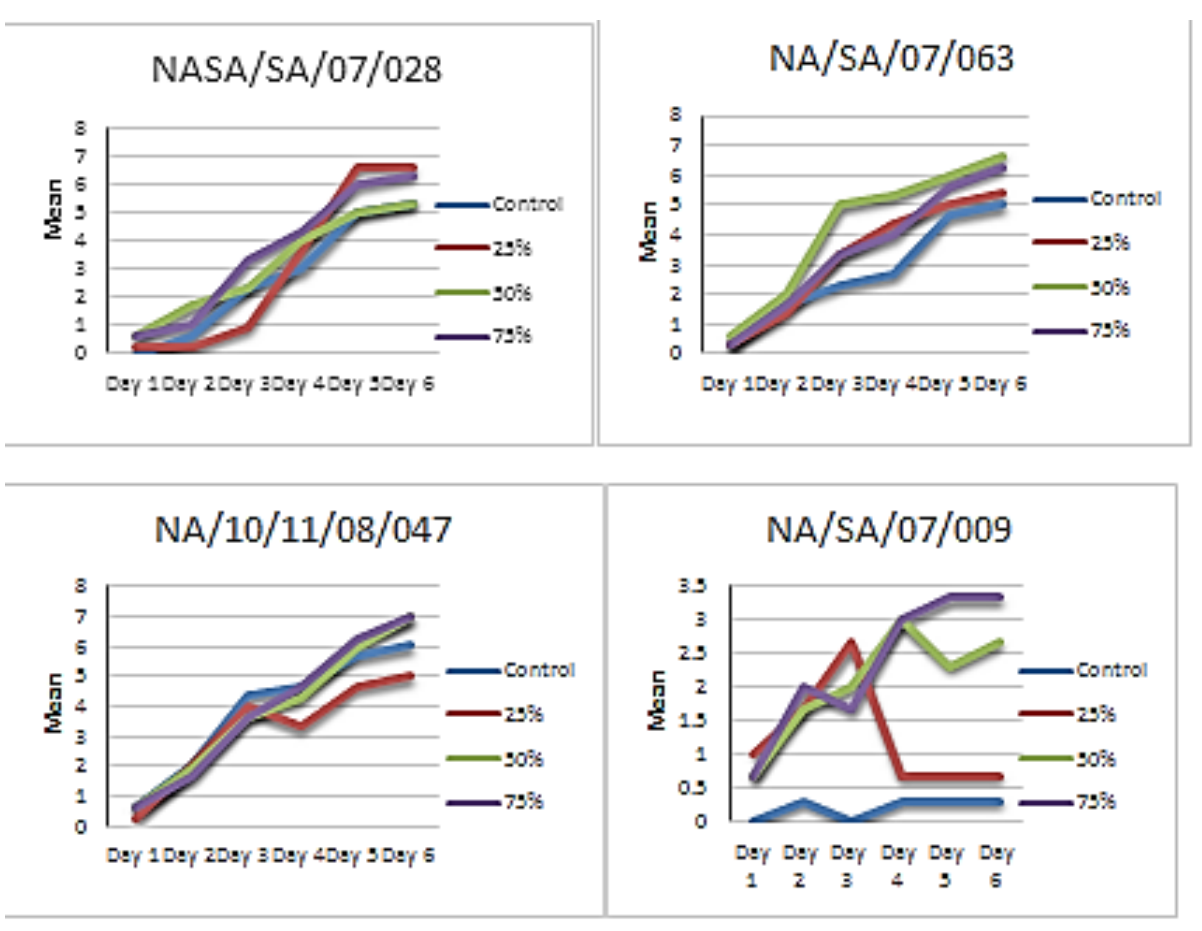

Fig 2. Treatment performance on all the accessions of Vigna unquiculata

\subsection{Correlation}

This study shows a positive correlation between the number of leaves damaged and number of days of the treatment. As days of treatments increases, the number of leaves damaged by insects increased (Table 3). 
Table 3. Correlation matrix between the number of leaves damaged and number of days of the treatment.

\begin{tabular}{lllll}
\hline & Control & $\mathbf{2 5 \%}$ & $\mathbf{5 0 \%}$ & $\mathbf{7 5 \%}$ \\
\hline Control & & 0.8890 & 0.8825 & 0.8976 \\
$25 \%$ & 0.8890 & & 0.8747 & 0.8651 \\
$50 \%$ & 0.8825 & 0.8747 & & 0.9472 \\
$75 \%$ & 0.8976 & 0.8651 & 0.9472 & \\
\hline
\end{tabular}

All correlations are significant at $\mathrm{p}<0.01$ level (2-tailed)

\section{Discussion}

There is an increase usage of cow dung for different purposes in different countries around the world (Okogbue and Ojo 2003). It has been used as mosquito repellent (Mandavgane et al. 2005). In this study, the potential of cow dung as insect repellent in Vigna unquiculata showed negative results. It was observed that more leaves were damaged at high concentration of cow dung treatment with respect to increasing number of days. The cowpea used for control and those that were treated, all had the leaves damaged. It was observed in this study that cowpeas treated with higher concentrations (50\% and $75 \%$ ) had more leaves damaged than $25 \%$ concentration and the control. Consequently, the treatments did not repel the insect pests of cowpea (Vigna unguiculata). This was contrary to the potential of cow dung being used as mosquito repellent, which is now a common practice in India (Atulesh 2011).

However, the inability of the treatment to repel insect pest maybe due to other factors that serve as limitations or barriers to this study. One of the limitations was the raining period during which the research was conducted. Another limitation could be using only one location for the study. Other different locations with different environmental conditions may produce different results. Sawadogo et al. (2009) posited that there may be variation in prevalence and distribution of cowpea insect pest among agro-climatic zones. Similarly, the study was carried out using one species of plant though with different accessions, but using different species of crops for this study may however, produce a different result.

\section{Conclusions}

This present study revealed that cow dung at different concentration treatments does not have the potential to repel insect pests of cowpeas, rather, 
it attracts more insect pests to these crops. Hence, it cannot be used as insect pest repellent of cowpea. Additionally, the properties of cow dung that is responsible for attracting insect pests of cowpea should be further examined. Nonetheless, government should encourage more research on alternate nonchemical approach to pest control on cowpea and other economic food crops through adequate funding.

\section{Acknowledgements}

We sincerely thank Kehinde Sowunmi for his assistance on statistical analysis. Anonymous reviewers for their critical feedbacks and editorial insights are acknowledged.

\section{References}

Ajeigbe HA, Singh B. 2006. Integrated pest management in cowpea: Effect of time and frequency of insecticide application on productivity. Crop Protection 25(9):920-925.

Atulesh 2011. Cow dung: A composted fertilizer. Retrieved from http://www.wealthywaste.com/ cow-dung-a-composted-fertilizer on September $9^{\text {th }}$, 2018

Dolvo F, Williams C, Soaka L. 2014. Cowpea: Home preparation and use in West Africa. International Research Centre. Ottawa. 308pp.

Emosairue S, Eze D, Okore K. 2014. Timing of insecticidal application in Vignaunguiculata (L.) Walp and its potential as late season crop in Calabar area, Nigeria. Journal of Applied Chemistry and Agricultural Resources 8 (2): 6-12.

Mandavgane SA, Pattalwar VV, Kalambe AR. 2005. Development of cow dung based herbal mosquito repellent. Natural Product Radiance 4(4): 270-273.

Nampala P, Ogenga-Latigo MW, Kyamanywa S, Adipala E, Karungi J, Oyobo N, Obuo JE, Jackai LE. 1999. Integrated management of major field pests of cowpea in eastern Uganda. African Crop Science Journal. 7(4): 479-486.

Okogbue EC, Ojo BO. 2003. Local production of renewable energy (biogas) from animal waste for domestic and laboratory uses. Nigerian Journal of Solar Energy 14: 121-125.

Olatunde JA, Odebiyi J, Chaing HS, Jackai LN. 2013. Identification of sources of resistance in cowpea (Vigna unguiculata) L. Walp. to Clavigralla tomentosicollis stai (Hemipera, coreidae). Journal on Insecticide Application 2(4): 455-461.

Sawadogo A, Thio BB, Kiemde S, Drabo I, Dabire C, Ouedraogo J, Mullens TR, Ehlers JD, Roberts PA. 2009. Distribution and Prevalence of Parasitic Nematodes of Cowpea (Vigna unguiculata) in Bukina Faso. Journal of Nematology 41 (2): 120-127.

Sexena RC. 2010. Natural resistance of plant to pests: Roles of Allelochemicals. American Chemical Society. Washington D. C. 235pp.

UCANR (University of California, Agriculture and Natural resource). 2017. UC Pest management guidelines. Retrieved from ipm.ucanr.edu on $27^{\text {th }}$ November 2018.

Tiroesele B, Sitwane M, Obopile M, Ullah MI, Ali S. 2017. Effects of effluent water on the abundance of cowpea insect pests. Environmental Monitoring and Assessment 189 (11): 110 . 